\title{
Metabolite profiles of common Stemphylium species
}

\author{
Andersen, Birgitte; Solfrizzo, Michelle; Visconti, Angelo
}

Published in:

Mycological Research

Publication date:

1995

Document Version

Publisher's PDF, also known as Version of record

Link back to DTU Orbit

Citation (APA):

Andersen, B., Solfrizzo, M., \& Visconti, A. (1995). Metabolite profiles of common Stemphylium species. Mycological Research, 6, 672-676.

\section{General rights}

Copyright and moral rights for the publications made accessible in the public portal are retained by the authors and/or other copyright owners and it is a condition of accessing publications that users recognise and abide by the legal requirements associated with these rights.

- Users may download and print one copy of any publication from the public portal for the purpose of private study or research.

- You may not further distribute the material or use it for any profit-making activity or commercial gain

- You may freely distribute the URL identifying the publication in the public portal

If you believe that this document breaches copyright please contact us providing details, and we will remove access to the work immediately and investigate your claim. 


\title{
Metabolite profiles of common Stemphylium species
}

\author{
BIRGITTE ANDERSEN ${ }^{1 *}$, MICHELE SOLFRIZZO² AND ANGELO VISCONTI \\ ${ }^{1}$ Department of Biotechnology, Building 221, Technical University of Denmark, DK-2800 Lyngby, Denmark \\ ${ }^{2}$ Istituto Tossine e Micotossine da Parassiti Vegetali, C.N.R., Viale L. Einaudi 51, I-70125 Bari, Italy
}

Thirty-three isolates of Stemphylium spp. have been analysed for their metabolite profiles. Five metabolites, stemphylin, stemphyloxin II, stemphyperylenol, stemphol and a stemphol related compound, have been detected by high-performance liquid chromatography and thin-layer chromatography and identified by their chromatographic and spectroscopic data $\left(R_{\mathrm{f}}\right.$ values, reflectance spectrum, retention index and ultraviolet spectrum). These metabolites have been used for the chemotaxonomical characterization of Stemphylium botryosum, S. herbarum, S. alfalfae, S. majusculum, S. sarciniforme, S. vesicarium, Pleospora herbarum and P. tarda.

Identification of fungi based exclusively on morphology is often a problem because of variations in conidial appearance within the same species or resemblance between different species. Thus, profiles of secondary metabolites have proven a good support to the morphology and have been used with great success in differentiating between species within Penicillium and Fusarium (Frisvad \& Filtenborg, 1989; Thrane, 1989; Andersen, 1991). It is often seen that two different fungal species have one or more metabolites in common but other metabolites will discriminate between the two species (Frisvad \& Filtenborg, 1989). Standards of mycotoxins and other secondary metabolites have been characterized in the same system used for establishing metabolite profiles (Frisvad \& Thrane, 1987; Singh et al., 1991; Frisvad \& Thrane, 1993) and are used for identification of compounds in metabolite profiles.

A general method for visualizing a metabolite profile is using high-performance liquid chromatography (hplc) with a diode array detector (DAD) (Frisvad \& Thrane, 1987). By means of the DAD detector the chromatographic peaks can be recognized by their uv spectra. It has been shown for both Penicillium and Fusarium that each species has a unique and specific hplc chromatogram (Frisvad \& Filtenborg, 1989; Thrane, 1989). Another and more rapid method for visualizing a metabolite profile is thin-layer chromatography (tlc) using the agar plug method (Filtenborg \& Frisvad, 1980; Frisvad, Filtenborg \& Thrane, 1989; Singh et al., 1991). The advantage of this method is that there is no chemical treatment of the metabolites and thereby less chance for formation of artefacts, which can give a distorted picture of metabolite profile. Reflectance spectra recorded from the tlc plate by a tic Scanner makes it possible to distinguish between different metabolites with the same $R_{\mathrm{f}}$-value and colour (Andersen, 1991). The two

\footnotetext{
* Corresponding author.
}

methods are complementary, since some metabolites are only detectable either by tlc or hplc.

This paper deals with some of the metabolites in the metabolite profile of Stemphylium from pure cultures and the use of their chromatographic and spectroscopic characteristics in determinating the fungal metabolite profile. For chemotaxonomic comparison of metabolite profiles from S. botryosum Wallr. and related species, isolates of $S$. herbarum E. G. Simmons, S. alfalfae E. G. Simmons, S. majusculum E. G. Simmons, S. sarciniforme (Cavara) Wiltshire, S. vesicarium (Wallr.) E. G. Simmons and Stemphylitm states of Pleospora herbarum (Pers.: Fr.) Rabenh. and P. tarda Simmons were investigated as well.

\section{MATERIALS AND METHODS}

Fungi and growth conditions. The following 33 isolates of different Stemphylium species and their teleomorphs Pleospora were screened for consistent production of metabolites: 12 isolates of $S$. botryosum (represented by IBT 8226 and IBT 8213) were obtained from rapeseeds in Italy and from barley kernels in Denmark, four isolates of S. herbarum (represented by IBT 8224) obtained from rapeseeds in Italy, two isolates of S. alfalfae (represented by IBT 8227) obtained from rapeseeds in Italy, five isolates of S. vesicarium (represented by IBT 8220) obtained from pear in Italy (2) and barley kernels in Denmark (3), four isolates of S. sarciniforme (represented by CBS 335.33), four isolates of $P$. herbarum (represented by IMI 130782), one of P. tarda (IMI 135456) and one of S. majusculum (IMI 135459).

Identification of isolates. All isolates were identified on PCA (potato carrot agar) (Simmons, 1992) according to the descriptions by Simmons (1969, 1985). One isolate from each species (S. botryosum, S. herbarum, S. alfalfae and S. vesicarium) was given an IBT number and taken as a representative for the 


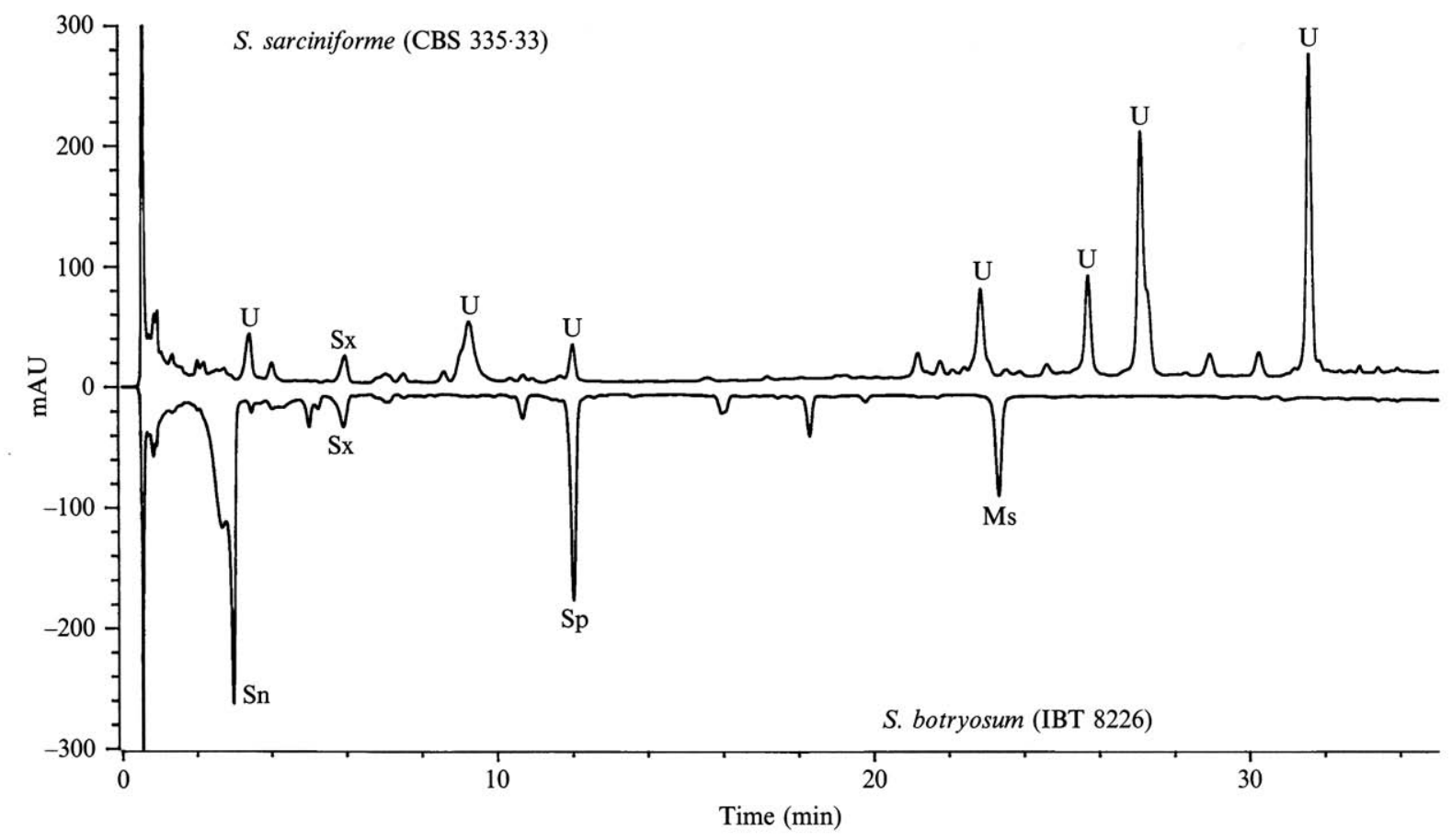

Fig. 1. Metabolite profiles of S. sarciniforme (IBT 8222) and S. botryosum (IBT 8226) from hplc. Sn, stemphylin; Sx, stemphyloxin II; Sp, stemphyperylenol; Ms, macrosporin; U, unknown compound.

group. Isolates with IBT numbers are held at the fungal collection at Department of Biotechnology, Technical University of Denmark, CBS number is held at the Centraalbureau voor Schimmelcultures, Baarn, The Netherlands and IMI numbers are held at the International Mycological Institute, Egham, Surrey, U.K.

Metabolite profile analyses. For metabolite profile analyses, each isolate was inoculated on seven Petri dishes $(90 \mathrm{~mm}$ diam.), each containing the following seven media: ALK (Alkaloid formation agar) (Reshetilova et al, 1992), DRYES (Dichloran Rose bengal Yeast Extract Sucrose agar) (Frisvad, 1983), MEA (Malt Extract Agar) (Pitt, 1979), NS (Nitrite Sucrose agar) (Frisvad, 1981), OAT (Oat meal agar) (Gams et al., 1987), PSA (Potato Sucrose Agar) (Booth, 1971) and SYES (Sigma Yeast Extract Sucrose agar) (Filtenborg, Frisvad \& Thrane, 1990). All media except ALK were given $1.0 \mathrm{ml}{ }^{-1}$ of trace metal solution ( $\mathrm{I} \cdot \mathrm{g} \mathrm{ZnSO}_{4} \cdot 7 \mathrm{H}_{2} \mathrm{O}, 0.5 \mathrm{~g} \mathrm{CuSO}_{4} \cdot 5 \mathrm{H}_{2} \mathrm{O}$, $100 \mathrm{ml}$ water) (Smith, 1949). After inoculation the Petri dishes were incubated at $25^{\circ} \mathrm{C}$ in the dark for $14 \mathrm{~d}$.

TLC. One agar plug (4 mm diam.) from each of the seven Petri dishes was applied in the same line to $0.25 \mathrm{~mm}$ silica gel 60 precoated plates with and without fluorescence indicator (Merck nos. 5715 and 5721, respectively). The plates were eluted in TEF (toluene/ethyl acetate/ $90 \%$ formic acid (5:4:1, $\mathrm{v} / \mathrm{v} / \mathrm{v})$ ). The metabolite profiles were visualized under uv light $(365$ and $254 \mathrm{~nm})$ and sprayed with $50 \% \mathrm{H}_{2} \mathrm{SO}_{4}$ in methanol or ANIS ( $1.8 \%$-methoxybenzaldehyde in methanol/glacial acetic acid/conc. $\left.\mathrm{H}_{2} \mathrm{SO}_{4}(14: 2: 1, \mathrm{v} / \mathrm{v} / \mathrm{v})\right)$. Reflectance spectra were recorded on a CAMAG tlc scanner II (Muttenz, Switzerland) with CATS3 software.

HPLC. The whole agar cultures of the seven Petri dishes were extracted with $150 \mathrm{ml}$ ethyl acetate and I $\mathrm{ml}$ formic acid and then with $150 \mathrm{ml}$ chloroform/methanol $(2: 1, \mathrm{v} / \mathrm{v})$. The extracts were pooled and evaporated to dryness. The residue was dissolved in $3 \mathrm{ml}$ acetonitrile and defatted with $6 \mathrm{ml}$ hexane. The hexane was discarded. The metabolites were separated by hplc analysis on a Hewlett Packard HP $1090 \mathrm{M}$ high-performance liquid chromatograph equipped with two pumps, a built-in diode array detector, an autosampler injection system $(10 \mu \mathrm{l})$ and an external computer control (HP 9000 Model 310). The column was a $100 \mathrm{~mm} \times 4.0 \mathrm{~mm}$ i.d. Nucleosil $5 \mu \mathrm{m} \mathrm{C}_{18}$ reversed phase column (Macherey-Nagel \& Co., Düren, Germany). A gradient solvent system consisting of acetonitrile with $0.01 \%$ trifluoroacetic acid and water as described by Frisvad \& Thrane (1987) was used with a flow rate at $2.0 \mathrm{ml} \mathrm{min}$. A series of alkylphenones was used as external standards for calculating a retention index (RI) for each peak in the chromatogram (Frisvad \& Thrane, 1987).

Identification of metabolites. The identity of the metabolites was confirmed by comparison with the authentic material, uv spectra and/or with tic data available from the literature. Standards of stemphylin (= altersolanol A) and macrosporin were kindly provided by Professor Akira Yagi, Faculty of Pharmacy \& Pharmaceutical Sciences, Fukuyama University, Hiroshima, Japan and G.W. van Eijk, Centraalbureau voor Schimmelcultures, Baarn, The Netherlands, respectively. Stemphol was obtained from a culture of $S$. botryosum on rice at Istituto Tossine e Micotossine da Parassiti Vegetali, Italy.

\section{RESULTS AND DISCUSSION}

\section{Metabolite profile analyses}

The metabolite profile of a Stemphylum isolate is composed by 15-20 well-defined spots on tlc and 10-15 major peaks on hplc. Most of the spots and peaks represent unknown 


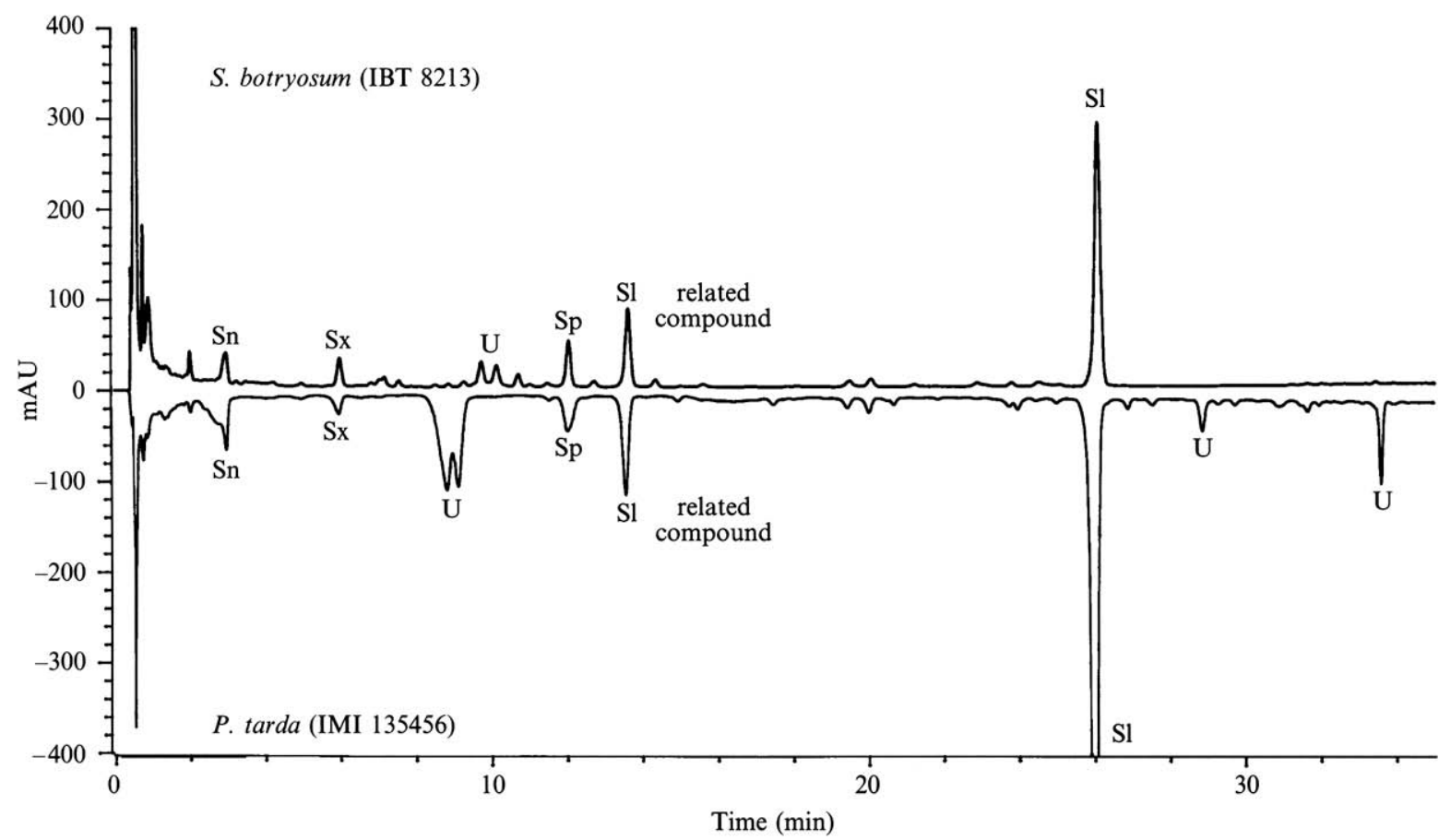

Fig. 2. Metabolite profiles of S. botryosum (IBT 8213) and P. tarda (IBT 8218) from hplc. Sn, stemphylin; Sx, stemphyloxin II; Sp, stemphyperylenol; $\mathrm{Sl}$, stemphol; U, unknown compound.

metabolites that are consistently produced and recognized in every isolate of the same species and can be used in construction of the metabolite profile. For comparison of metabolite profiles from hplc two profiles (S. botryosum and S. sarciniforme, respectively) are shown in Fig. 1. The two isolates have only few metabolites in common, meaning that both the retention indices and the uv spectra have to be identical. Stemphyloxin II is the only known metabolite the two isolates have in common. A chemotaxonomic segregation can be possible because each species produced metabolites that are not found in the other one. Figure 2 shows metabolite profiles from hplc of $S$. botryosum and its teleomorph Pleospora tarda. The two isolates have at least six metabolites in common. It is often seen that the teleomorph state produces a number of additional metabolites (Wicklow, 1988) but the metabolite profile is recognizable. Unknown metabolites are marked with a ' $U$ ' in Figs $I$ and 2.

\section{Identification of metabolites}

Five major compounds, namely stemphylin, stemphyloxin II, stemphyperylenol, stemphol and a stemphol related compound have been identified and placed in the metabolite profile of Stemphylium species on the basis of their uv spectral characteristics, tlc and hplc properties and by comparison with the authentic material. The chromatographic and spectroscopic data for all compounds are given in Tables 1 and 2 . The structures of the first four metabolites are given in Fig. 3.

Stemphylin. The phytotoxin, stemphylin, is visible on tlc plate as a yellow spot in daylight without spraying. Stemphylin is identical to altersolanol A (Assante \& Nasini, 1987) and has been isolated from S. botryosum var. lactucum (Barash et al., 1978), Alternaria porri and A. solani (Montemurro \& Visconti, 1992).

Table 1. Chromatographic and spectroscopic data of metabolites in the metabolite profile on $\mathrm{HI}^{\mathbf{a}}$

\begin{tabular}{|c|c|c|c|c|c|c|}
\hline & \multirow[b]{2}{*}{$R_{\mathrm{f}}$} & \multirow[b]{2}{*}{$R_{\mathrm{fg}}{ }^{\mathrm{b}}$} & \multicolumn{3}{|l|}{ Detection } & \multirow{2}{*}{$\begin{array}{l}\text { Reflectance" } \\
\text { spectra }\end{array}$} \\
\hline & & & At $366 \mathrm{~nm}$ & $\mathrm{H}_{2} \mathrm{SO}_{4}{ }^{11}$ & ANIS and heat ${ }^{\mathrm{e}}$ & \\
\hline Stemphylin & 16 & 47 & Orange brown & Brown & Yellow brown & $217^{*}(64), 235(38), 270^{*}(100), 328(10), 442^{*}(55)$ \\
\hline Stemphyloxin II & 23 & 72 & $\longrightarrow^{p}$ & $\longrightarrow$ & $\ldots$ & $194^{*}(40), 229(23), 276^{*}(100)$ \\
\hline Stemphyperylenol & 34 & 105 & Yellow & Orange & Orange red & $200(30), 218^{*}(42), 234(23), 262^{*}(100), 291(13), 341^{*}(59)$ \\
\hline Stemphol & 70 & 219 & Yellow green & Orange red & Red & $197^{*}(84), 219 \operatorname{sh}(57), 237(50), 272^{*}(100), 300(44), 352^{*}(88)$ \\
\hline $\begin{array}{l}\text { Stemphol related } \\
\text { compound }\end{array}$ & 44 & 136 & Yellow green & Orange red & Red & $198^{*}(92), 266 \operatorname{sh}(54), 239(40), 27 \mathrm{I}^{*}(100), 300(32), 352^{*}(68)$ \\
\hline \multicolumn{7}{|c|}{ All data are recorded on tlc plates with fluorescence indicator eluted in TEF. } \\
\hline \multicolumn{7}{|c|}{ " $R_{\mathrm{f}}$ values relative to griseofulvin, which has been given the value 100 calculated on plates with fluorescence indicator. } \\
\hline \multicolumn{7}{|c|}{ "Reflectance maxima $\left({ }^{*}\right)$, shoulders (sh) and minima recorded expressed in $\mathrm{nm}$ and relative intensities in per cent (in parentheses). } \\
\hline \multicolumn{7}{|c|}{ "Colours on plates irradiated at $366 \mathrm{~nm}$. } \\
\hline \multicolumn{7}{|c|}{ "Colours on plates after heating and exposed to daylight. } \\
\hline : Only & & & 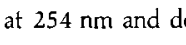 & d & & \\
\hline
\end{tabular}


Table 2. Chromatographic and spectroscopic data of metabolites in the metabolite profile on hplc

\begin{tabular}{|c|c|c|}
\hline & $u v-V I S$ spectra ${ }^{a}$ & $\begin{array}{l}\text { Retention index } \\
\text { value }\end{array}$ \\
\hline Stemphylin & $\begin{array}{l}203(54), 221^{*}(100), 241(28) \\
268^{*}(43), 331(3), 429(13)\end{array}$ & 726 \\
\hline Stemphyloxin II & $215 \operatorname{sh}(100), 239(32), 277^{*}(88)$ & 787 \\
\hline Stemphyperylenol & $\begin{array}{l}216^{*}(100), 239(23), 261^{*}(77) \\
291(6), 340^{*}(23)\end{array}$ & 909 \\
\hline Stemphol & $\begin{array}{l}205^{*}(100), 231 \text { sh }(19), 251(1) \\
273^{*}(2)\end{array}$ & 1200 \\
\hline $\begin{array}{l}\text { Stemphol related } \\
\text { compound }\end{array}$ & $\begin{array}{l}205^{*}(100), 231 \text { sh }(18), 251(1) \\
271^{*}(2)\end{array}$ & 921 \\
\hline \multicolumn{3}{|c|}{$\begin{array}{l}\text { absorption maxima }\left({ }^{*}\right) \text {, shoulders }(\mathrm{sh}) \text { and minima recorded in } \\
\text { acetonitrile/water gradient. Wavelengths are expressed in } \mathrm{nm} \text {. Percentages } \\
\text { are given in parentheses. }\end{array}$} \\
\hline
\end{tabular}

(A)<smiles>COc1cc(O)c2c(c1)C(=O)C1=C(C2=O)C(O)C(O)C(C)(O)C1O</smiles>

(B)<smiles>O=C1CC(O)C2c3ccc(O)c4c3C(c3ccc(O)c1c32)C(O)CC4=O</smiles>

(C)<smiles>CCC(CO)C1C(=O)C2(C)C(=CO)C(O)(C1=CO)C1CC(C)(O)CC(C)C12</smiles><smiles>CCCCCc1cc(O)c(CCCC)c(O)c1</smiles>

Fig. 3. The structures of the four known metabolites. (A) Stemphylin, (B) stemphyperylenol, (C) stemphyloxin II and (D) stemphol.
Stemphyloxin II. Stemphyloxin II is not considered to be a natural metabolite, but an artefact of stemphyloxin I, which is easily converted to its tautomer, stemphyloxin II, by acid or base (Barash et al., 1982). Stemphyloxin I shows an uv maximum at $282 \mathrm{~nm}$ in acidic solution and an uv maximum at $303 \mathrm{~nm}$ in basic solution. This shift in absorbance that was not exhibited by the partially purified compound. Since the agar cultures are extracted with a strong acid it is assumed that all the produced stemphyloxin I is transformed to stemphyloxin II. Stemphyloxin I and II have previously been isolated from S. botryosum f. sp. lycopersici (Barash et al., 1982; Manulis et al., 1984).

Stemphyperylenol. Stemphyperylenol gives the most conspicuous spot in the metabolite profile on tlc when the plate is sprayed with $\mathrm{H}_{2} \mathrm{SO}_{4}$. The spot is bright orange under $365 \mathrm{~nm}$ uv light. Stemphyperylenol has been previously been isolated from S. botryosum var. lactucum (Arnone et al., 1986).

Stemphol. Stemphol from S. botryosum (IBT 8213) proved to be identical to a standard of stemphol derived from rice cultures of S. botryosum (Solfrizzo et al., 1994). It exhibits a dark red spot on tlc in daylight, when sprayed with ANIS and heated with a hair dryer. The red spot fades to a reddish brown spot after cooling at room temperature. Stemphol is also produced by S. majusculum (Stodola et al., 1973).

Stemphol related compound. An unknown stemphol derivative was isolated from S. botryosum (IBT 8213). The structure of this compound could not be fully elucidated because of the small amount of compound available. However, its uv spectrum was identical to that of authentic stemphol. Treatment with $\mathrm{H}_{2} \mathrm{SO}_{4}$ and ANIS gave the same reaction for stemphol and the stemphol related compound (see Table 1 and 2). These findings indicate that the stemphol related compound must have the same chromophore and the same functional groups as stemphol. A mass spectrum of the stemphol related compound showed a molecular ion at 252 mass units compared with that of stemphol at 236 mass units. This could suggest a stemphol structure with an addition $-\mathrm{OH}$, which is in agreement with the increased polarity of the compound.

Table 3 shows the result of the screening of 33 Stemphylium isolates for production of the five metabolites considered herein. Within the species of $S$. botryosum two different chemotypes were identified based on their metabolite profiles detected by tlc and hplc analyses. S. botryosum Type I which is able to produce all five metabolites and S. botryosum Type II only producing stemphylin, stemphyloxin II and stemphyperylenol. S. botryosum Type II is also able to produce macrosporin, a metabolite known from Altemaria spp. (Montemurro \& Visconti, 1992). S. herbarum produces only stemphyloxin II and stemphyperlenol. Table 3 also shows that the screened isolates of $S$. vesicarium and S. alfalfae are able to produce stemphol, which has not been reported previously.

\section{CONCLUSION}

Chemotaxonomy and morphology is a powerful combination for identification of Stemphylium. Both hplc and tlc 
Table 3. Metabolite production in different species of Stemphylium

\begin{tabular}{|c|c|c|c|c|c|}
\hline $\begin{array}{l}\text { Species }^{\mathrm{a}} \\
\text { (numbers } \\
\text { of isolates) }\end{array}$ & $\begin{array}{l}\text { Stem- } \\
\text { phylin }\end{array}$ & $\begin{array}{l}\text { Stem- } \\
\text { phyloxin } \\
\text { II }\end{array}$ & $\begin{array}{l}\text { Stemphy- } \\
\text { perylenol }\end{array}$ & Stempho] & $\begin{array}{l}\text { Stemphol } \\
\text { related } \\
\text { compound }\end{array}$ \\
\hline P. tarda (1) & + & + & + & + & + \\
\hline \multicolumn{6}{|l|}{ S. botryosurn } \\
\hline Type $I^{b}(5)$ & + & + & + & + & + \\
\hline Type II' (7) & + & + & + & ND & ND \\
\hline P. herbarum (4) & + & + & + & ND & ND \\
\hline S. herbartm $(4)$ & ND & + & + & ND & ND \\
\hline S. maiusculum (1) & ND & + & + & + & + \\
\hline S. alfalfae (2) & ND & + & ND & ND & ND \\
\hline S. sarciniforme (4) & ND & + & $\mathrm{ND}$ & ND & ND \\
\hline S. vesicarium (5) & + & + & + & + & ND \\
\hline \multicolumn{6}{|c|}{ - P., Pleospora; S., Stemphylium. } \\
\hline \multicolumn{6}{|c|}{ b Type I group is represented by isolate IBT 8213 . } \\
\hline \multicolumn{6}{|c|}{ " Type II group is represented by isolate IBT 8226 . } \\
\hline \multicolumn{6}{|c|}{ ND, not detected on tlc or hplc. } \\
\hline
\end{tabular}

analyses of the metabolite profile provide useful information in the chemotaxonomic characterization of Stemphylium species. However, chromatographic and spectroscopic data $\left(R_{\mathrm{f}}\right.$ values, reflectance spectra, retention indices and ultraviolet spectra) of the metabolites investigated and the other unknown metabolites in the profile should always be used together and in combination with morphological characteristics in order to avoid misidentification of metabolites or isolates. The current investigation represents an example of the combined application of hplc and tlc to analyse the metabolite profiles of a limited number of Stemphylitum isolates, which enables the mycologist to identify or confirm different species of Stemphylium on the basis of five known metabolites. Moreover, the two distinct metabolite profiles within the species $S$. botryosum suggest further studies to test the two chemotypes for other differences, e.g. pathogenicity towards different host plants.

We wish to thank Professor Akira Yagi of Fukuyama University, Japan, for the standard of altersolanol A.

\section{REFERENCES}

Anderson, B. (1991). Consistent production of phenolic compounds by Penicillium brevicompactum for chemotaxonomic characterization. Antone van Leeuwenhoek 60, 115-123.

Arnone, A., Nasini, G., Merlini, L. \& Assante, G. (1986). Secondary mould metabolites. Part 16. Stemphyltoxins, new reduced perylenequinone metabolites from Stemphylium botryosum var. lactucum. Journal of Chemical Society, Perkin Transactions l, 525-530.

Assante, G. \& Nasini, G. (1987). Identity of the phytotoxin stemphylin from Stemphylium botryosum with altersolanol A. Phytochemistry 26, 703-705.

Barash, I., Netzer, D., Nachmias, A. \& Strobel, G. A. (1978). Differential effect of phytotoxins produced by Stemphylium botryosum on susceptible and resistant lettuce cultivars. Phytoparasitica 6, 95-98.

Barash, I., Pupkin, G., Netzer, D. \& Kashman, Y. (1982). A novel enolic $\beta$ ketoaldehyde phytotoxin produced by Stentphylium botryosum f. sp. lycopersici. Plant Physiology 69, 23-27.
Booth, C. (1971). The Genus Fusarium. Commonwealth Mycological Institute. Kew, Surrey, U.K.

Filtenborg, O. \& Frisvad, J. C. (1980). A simple screenings-method for toxigenic mold in pure cultures. Lebensmittel-Wissenschaft und-Technologie 13, 128-130.

Filtenborg, O. Frisvad, J. C. \& Thrane, U. (1990). The significance of yeast extract composition on metabolite production in Penicilium. In Modern Concepts in Penicillium and Aspergillus Classificution (ed. R. A. Samson \& J. I. Pitt). pp. 433-441. Plenum Press: New York, U.S.A.

Frisvad, J. C. (1981). Physiological criteria and mycotoxin production as aids in identification of common asymmetric penicillia. Applied and Environmental Microbiology 41, 568-579.

Frisvad, J. C. (1983). A selective and indicative medium for groups of Penicillum viridicatum producing different mycotoxins on cereals. Journal of Applied Bacteriology 54, 409-416.

Frisvad, J. C. \& Filtenborg, O. (1989). Tervertıcillate penicillia: chemotaxonomy and mycotoxins production. Mycologia 81, 837-861.

Frisvad, J. C., Filtenborg, O. \& Thrane, U. (1989). Analysis and screening for mycotoxins and other secondary metabolites in fungal cultures by thinlayer chromatography and high-performance liquid chromatography. Archives of Environmental Contamunation and Toxicology 18, 331-335.

Frisvad, J. C. \& Thrane, U. (1987). Standardized high-performance liquid chromatography of 182 mycotoxins and other fungal metabolites based on alkylphenone retention indices and UV-VIS spectra (diode array detection). Journal of Chromatography 404, 195-214.

Frisvad, J. C. \& Thrane, U. (1993). Liquid column chromatography of mycotoxins. In Chromatography of Mycotoxins. Techniques and Applicatons (ed. V. Betina), pp. 253-372. Elsevier: Amsterdam, Netherlands.

Gams, W., van der Aa, H. A., van der Plaats-Niterink, A. J., Samson, R. A. \& Stalpers, J. A. (1987). CBS Course of Mycology. Centraalbureau voor Schimmelcultures: Baarn, Netherlands.

Manulis, S., Kashman, Y., Netzer, D. \& Barash, I. (1984). Phytotoxins from Stemphylium botryosum: structural determination of stemphyloxin II, production in culture and interaction with iron. Phytochemistry 23, 2193-2198

Montemurro, N. \& Visconti, A. (1992). Alternaria metabolites - chemical and biological data. In Alternaria: Biology. Plant Diseases and Metabolites (ed. J. Chelkowski \& A. Visconti), pp. 449-557. Elsevier : Amsterdam, Netherlands.

Pitt, J. I. (1979). The Genus Penicillium and its Teleomorphic States Eupenicillium and Talaromyces. Academic Press: London, U.K.

Reshetilova, T. A., Solov'eva, T. F., Bashunov, B. P. \& Kozlovskii, A. G. (1992). [Investigation of alkaloid formation by certain species of fungi of the Penicillium genus.] Microbiologiya 61, 873-879. [In Russian]

Simmons, E. G. (1969). Perfect states of Stemphylium. Mycologia 61, 1-26.

Simmons, E. G. (1985). Perfect states of Stemphylium II. Sudowia 38, 284-293.

Simmons, E. G. (1992). In Alternaria: Biology, Plant Diseases and Metabolites (ed. J. Chelkowski \& A. Viscont1), pp. 1-35. Elsevier: Amsterdam, Netherlands

Singh, K., Frisvad, J. C., Thrane, U. \& Mathur, S B. (1991). An Illustruted Manual on Identritication of Some Seed-borne Aspergilli. Fusaria, Penicillia and their Mycotoxms. lordbrugsforlaget: Frederiksberg, Denmark.

Smith, G. (1949). The effect of adding trace metal to Czapek-Dox culture medium. Transactions of the British Mycological Society 32, 280-283.

Solfrizzo, M., Strange, R. N., Sabia, C. \& Visconti, A. (1994). Production of a toxin stemphol by Stemphylium species. Natural Toxins 2, 14-18.

Stodola, F. H., Weisleder, D. \& Vesonder, F. (1973). A new dialkylresorcinol from Stemphylium majusculum. Phytochemustry 12, 1797-1798.

Thrane, U. (1989). Fusurum species and their specific profiles of secondary metabolites. In Fusarium Mycotoxins, Taxonomy and Pathogentity (ed. J. Chelkowski), pp. 199-220. Elsevier: Amsterdam, Netherlands.

Wicklow, D. T. (1988). Metabolites in the coevolution of fungal chemical defence systems. In Coevolution of Fingi with Plants ant Ammuls (ed. K. A Pirozynskı \& D. L. Hawksworth), pp. 173-202. Academic Press: London, U.K. 